\title{
Glass and Glass-Ceramics Produced from Fly Ash and Boron Waste
}

\author{
E. ERCEnK ${ }^{a, *}, \mathrm{U} \cdot \mathrm{SEN}^{a}$, G. BAYRAK ${ }^{b}$ AND S. YILMAZ ${ }^{a}$ \\ ${ }^{a}$ Sakarya University, Engineering Faculty, Department of Metallurgical and Materials Engineering \\ Esentepe Campus, 54187 Sakarya, Turkey \\ ${ }^{b}$ Sakarya University, Vocational School of Arifiye, Machinery and Metal Technology Department \\ 54580 Sakarya, Turkey
}

\begin{abstract}
In the current study, the effect of boron waste addition on some properties of fly ash based glass and glass-ceramics were investigated. The powder compositions including 10, 30, and $50 \mathrm{wt} \%$ boron waste was prepared. All the investigated compositions were melted at $1500^{\circ} \mathrm{C}$ by using electrical furnaces. Melting structures were cast into the graphite mold. Thus, fly ash-boron waste based glass materials were produced. To transform the glass-ceramic, crystallization process was performed. Crystallization and glass-transition temperatures were determined by differential thermal analysis. Highly dense and crystalline materials, predominantly composed of diopside and augite together with tincalconite and residual glassy phase, were detected by X-ray diffraction analysis after heat treatment at 800,900 , and $1000{ }^{\circ} \mathrm{C}$ for $1 \mathrm{~h}$. For the glass and glass-ceramic samples, mechanical tests such as hardness and fracture toughness were realized. A boron waste addition has a positive effect on the hardness of the specimens unlike the fracture toughness results. Furthermore, produced glass-ceramic materials were characterized via scanning electron microscopy.
\end{abstract}

DOI: 10.12693/APhysPolA.125.626

PACS: 61.43.Fs, 64.70.P-, 61.05.cp, 81.70.Pg, 62.20.Qp

\section{Introduction}

One of the industrial waste material fly ash released by factories and thermal power plants have been increased throughout the world. This situation emerged as a serious environmental and economical problem [1]. Fly ash consists of fine, powder particles predominantly spherical in shape, either solid or hollow, and mostly glassy (amorphous) in nature. Low to medium bulk density, high surface area and light texture are the main physical characteristics of the fly ashes. The dominant oxides in fly ash are $\mathrm{SiO}_{2}$ (over the $50 \%$ ), $\mathrm{Al}_{2} \mathrm{O}_{3}, \mathrm{Fe}_{2} \mathrm{O}_{3}$ and $\mathrm{MgO}$ $[2,3]$. Fly ash can be used for glass and glass-ceramic materials production owing to these oxides.

Boron is an important element due to its some properties such as optical, thermal, and electrical. Because of this, it has wide using area as fiberglass insulation, borosilicate glass, metal welding and pharmaceutical manufacturing, and is a dopant for semiconductors. Boron compounds are used to produce borosilicate glass. Boron oxide joins to the glass structure as a glass constructive material. These glasses are used in chemically resistant containers and piping to fiber composites, and from pharmaceutical and sealing glasses to nuclear waste immobilization. Boron has been found as a mineral structure in nature. It is generally obtained by refinement of boron ore, mainly colemanite, and borax [4]. Turkey holds $63 \%$ of the total boron reserves of the world with 640 million tonnes. Boron ores in Turkey are colemanite,

\footnotetext{
*corresponding author; e-mail: ercenk@sakarya.edu.tr
}

ulexite and tincal. Eti-bor Kırka Borax Company is the biggest borax producer in Turkey $[5,6]$.

The aim of the present study is to prepare the new glass and glass-ceramic materials obtained from fly ash and boron waste. The effect of boron waste on mechanical and microstructural characteristics of fly ash based glass and glass-ceramics was studied.

\section{Experimental procedure}

Fly ash taken from from Seyitomer Thermal Power Plant (Turkey) and boron waste obtained from Eti-bor Kırka Borax Company (Turkey) were used in this study.

TABLE

Chemical analysis of the used raw materials (wt\%).

\begin{tabular}{c|c|c}
\hline \hline Constituent oxides & Fly ash & Boron waste \\
\hline $\mathrm{SiO}_{2}$ & 56.89 & 11.42 \\
$\mathrm{Al}_{2} \mathrm{O}_{3}$ & 17.24 & 1.52 \\
$\mathrm{Fe}_{2} \mathrm{O}_{3}$ & 10.62 & 0.28 \\
$\mathrm{MgO}$ & 5.63 & 8.02 \\
$\mathrm{CaO}$ & 4.31 & 25.17 \\
$\mathrm{SO}_{3}$ & 2.39 & 0.26 \\
$\mathrm{~K}_{2} \mathrm{O}$ & 1.55 & 0.73 \\
$\mathrm{Na}_{2} \mathrm{O}$ & 0.58 & 10.56 \\
$\mathrm{TiO}_{2}$ & 0.67 & - \\
$\mathrm{P}_{2} \mathrm{O}_{5}$ & 0.12 & - \\
$\mathrm{B}_{2} \mathrm{O}_{3}$ & - & 14.68 \\
$\mathrm{LOI}$ & 0.445 & 24.98
\end{tabular}

The chemical analysis of the raw materials in the study is given in Table (LOI $=$ loss on ignition). The fly ash powders including 10,30 , and $50 \mathrm{wt} \%$ boron waste were 
mixed by using the alumina ball mill for $1 \mathrm{~h}$ and then were melted in Pt crucibles at $1500^{\circ} \mathrm{C}$ for $1 \mathrm{~h}$, in a Herause electrical furnace. Glasses in bulk form were produced by casting of molten on graphite molds and subsequent immediate annealing at $600{ }^{\circ} \mathrm{C}$ for $1 \mathrm{~h}$. The glasses were cooled down to room temperature at a rate of $3{ }^{\circ} \mathrm{C} / \mathrm{min}$. To realize the crystallization of these bulk glass samples, heat treatments at 800,900 , and $1000^{\circ} \mathrm{C}$ for $1 \mathrm{~h}$ in Protherm electrical furnace were performed. Both heating and cooling processes of the samples were performed at a rate of $5{ }^{\circ} \mathrm{C} / \mathrm{min}$. Heat treatment temperature was determined using differential thermal analysis (DTA, TA Instruments, Q-600) results. DTA experiment was realized in air atmosphere up to $1050^{\circ} \mathrm{C}$ with $10^{\circ} \mathrm{C} / \mathrm{min}$ heating rate. The single-stage method for heat treatment was preferred because glass transition and crystallization temperatures were close to each other. The crystalline phases in glass-ceramics were characterized by XRD (Rigaku D/Max). The detector was scanned over a range of $2 \theta$ angles from $10^{\circ}$ to $90^{\circ}$. SEM (JEOL 6060) was employed for microstructure observations. The mechanical properties were evaluated by Vickers microhardness indenter (Future-Tech FM 700), load of 25 gf; each measurement was made with five samples. The micro-hardness was calculated from the diagonal length of the indentation optically determined for each indentation. The fracture toughness was determined by the indentation technique. Polished specimens were indented at 5 separated locations. The test conditions are determined as 500 gf test load for $20 \mathrm{~s}$.

\section{Experimental results}

The XRD results of glass samples including $50 \%$ boron waste showed that the structures were amorphous, predominantly (Fig. 1a). Some weak peaks in the glass compositions were observed, it is probable that these crystalline phases were formed due to annealing process. In order to identify the crystalline phase(s), $\mathrm{X}$-ray scans were also carried out on glass-ceramic samples. The phases identified in the glass-ceramic samples are andesine $\left[\mathrm{Na}_{0.499} \mathrm{Ca}_{0.491}\left(\mathrm{Al}_{1.488} \mathrm{Si}_{2.506} \mathrm{O}_{8}\right)\right]$, augite $\left[\mathrm{Ca}(\mathrm{Mg}, \mathrm{Fe}) \mathrm{Si}_{2} \mathrm{O}_{6}\right]$, tincalconite $\left[\mathrm{Na}_{2} \mathrm{~B}_{4} \mathrm{O}_{7} \cdot 5 \mathrm{H}_{2} \mathrm{O}\right]$ and diopside $\left[\mathrm{Ca}_{1.007}\left(\mathrm{Mg}_{0.805} \mathrm{Fe}_{0.214}\right)\left(\left(\mathrm{Si}_{1.75} \mathrm{Fe}_{0.241}\right) \mathrm{O}_{6}\right)\right]$ seen in Fig. 1b. Andesine, augite, and diopside are common phases for fly ash based glass-ceramics [7, 8]. Peak intensities increased with increasing boron waste content and temperature. When the temperature reached $1000{ }^{\circ} \mathrm{C}$, the peaks intensities that increased from B10 sample to B50 sample presented the experimental evidence of increase in crystallinity. In general, overlapping of the peaks was determined due to similar chemical combination. The peaks of tincalconite phase were not observed in the XRD patterns of the B10 sample compared to the B50 sample. Similarly, this peak was not identified in the XRD patterns of the samples sintered at $800^{\circ} \mathrm{C}$. This situation shows that the tincalconite phase crystallizes above $800^{\circ} \mathrm{C}$, probably.

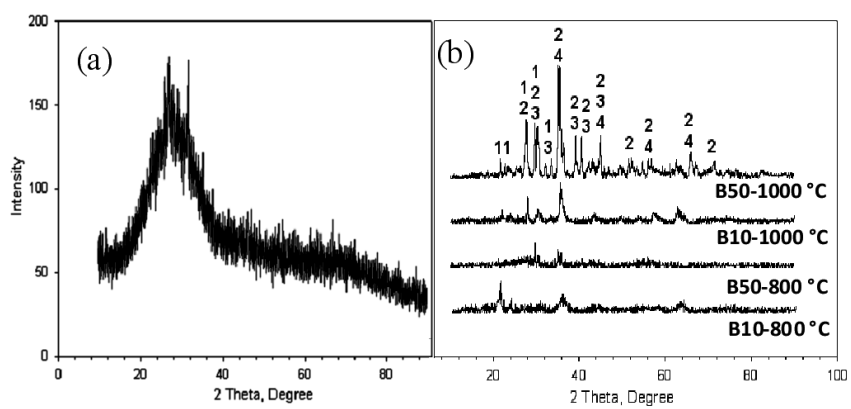

Fig. 1. XRD patterns of glass and glass-ceramic samples depending on boron waste content and temperature: (a) glass sample, (b) glass-ceramic samples (1 andesine, 2 - augite, 3 - tincalconite, 4 - diopside).

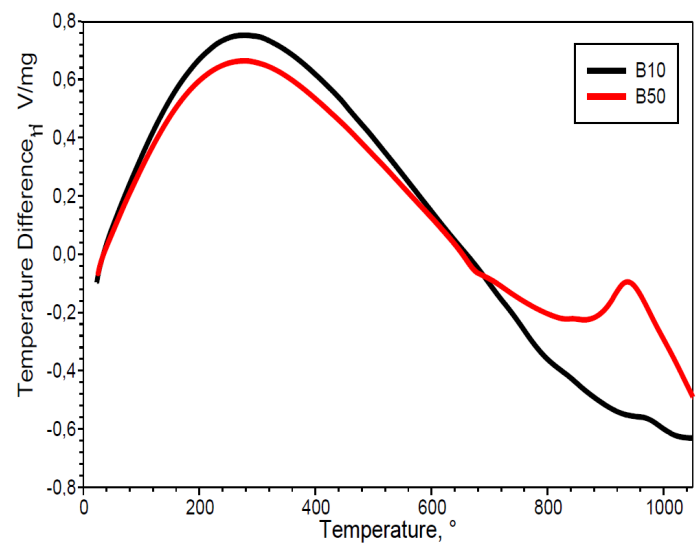

Fig. 2. DTA curves of B10 and B50 samples.

Fly ash has a high $\mathrm{SiO}_{2}$ content according to boron waste. Because of this, the melting tendency of fly ash is lower than the boron waste. In the XRD patterns of glass-ceramic samples, strong peaks were determined on the sample that has high boron waste content than the samples including low boron waste content. $\mathrm{B}_{2} \mathrm{O}_{3}$ in boron waste causes glass structure formation, low viscosity and better crystallinity. The crystallization process in lower temperature provided that the glasses including high boron waste crystallize easily.

The DTA results of the B10 and B50 samples can be seen in Fig. 2. The DTA curves for the glasses showed a very indistinct endothermic concave corresponding to the glass transition temperature $\left(T_{\mathrm{g}}\right)$. This transition was followed by one exothermic peak corresponding to the crystallization temperature $\left(T_{\mathrm{p}}\right)$. Both glass transition and crystallization temperatures of the samples decrease with increasing boron waste content. From Fig. 2, the boron waste addition to fly ash from 10 to $50 \mathrm{wt} \%$ caused a decrease in $T_{\mathrm{g}}$ from $925^{\circ} \mathrm{C}$ to $885^{\circ} \mathrm{C}$. In the B50 sample, the DTA curve showed an exothermic peak at $930^{\circ} \mathrm{C}$ for the crystallization, it was at $965^{\circ} \mathrm{C}$ for $\mathrm{B} 10$ sample. It is obvious that the presence of boron waste favors crystallization. Thus, the crystallization degree is clearly a function of the composition. $\mathrm{B}_{2} \mathrm{O}_{3}$ content 
tends to reduce glass transition and crystallization temperatures [9].

Figure 3 shows the values of microhardness and fracture toughness of glass and glass-ceramics. The results indicated that the hardness of the glass-ceramic materials were higher than the glass materials. Hardness is directly related to strength, elastic constants and crystallinity of glass-ceramics. With increase in temperature, the heat treatment time for higher crystallinity of glass-ceramics decreased. Thus, crystallization possibilities of the structure increase in the same treatment condition. The hardness of glass and glass-ceramics (Fig. 3a) increased depending on sintering temperature and glass-ceramic transformation. XRD results showed that boron waste additions caused better crystallization conditions.
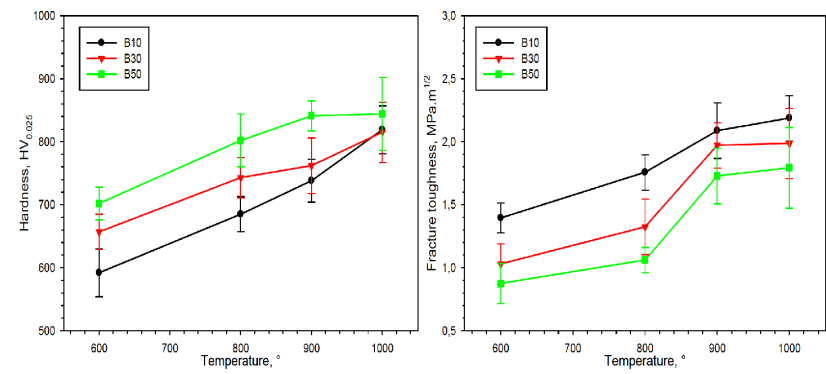

Fig. 3. Hardness and fracture toughness curves of the samples: (a) hardness, (b) fracture toughness.

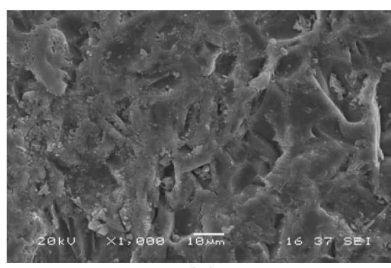

(a)

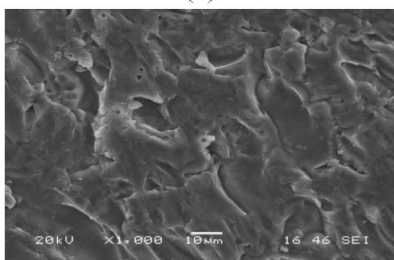

(c)

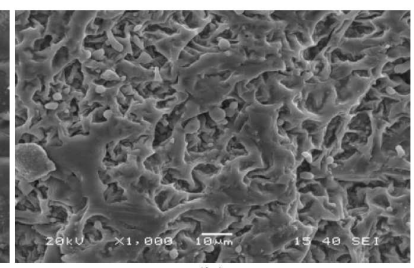

(b)

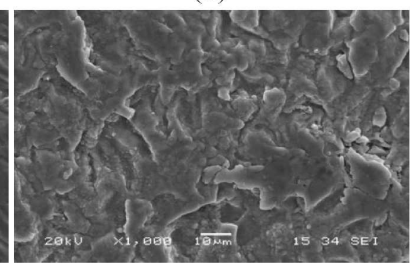

(d)
Fig. 4. SEM images of the glass-ceramic sample: (a) B10 sintered at $800^{\circ} \mathrm{C}$, (b) B50 sintered at $800^{\circ} \mathrm{C}$,

(c) B10 sintered at $1000^{\circ} \mathrm{C}$, (d) B50 sintered at $1000^{\circ} \mathrm{C}$.

SEM images of the glass-ceramic samples depending on temperature and boron waste content can be seen in Fig. 4. In general, dense and compact structures were observed from these microstructure. Increase in sintering temperature caused more dense structures formation.

Boron waste addition provided formation of the structure exhibiting distinctive grain boundary. Especially, the B50 glass-ceramic samples have been marked in terms of grain sizes compared to the B10 glass-ceramic samples.
Large and irregular crystals were observed in Fig. 4b. Decrease in glass transition and crystallization temperatures thanks to boron addition indicated suitable conditions for crystallization. This situation was confirmed by microstructures, glassy structure (grain boundaries cannot be distinguished) was evident in Fig. 4a,c compared to Fig. $4 \mathrm{~b}, \mathrm{~d}$.

\section{Summary}

In this study, two different waste materials were employed to produce glass and glass-ceramic materials. The purpose of the study was to present the effect of boron waste on vitrification, crystallization, and mechanical properties of fly ash based glass and glass-ceramics. The structure was detected by XRD as amorphous before the heat treatment process. Andesine, augite, tincalconite, and diopside phases were determined via heat treatment. Boron waste material caused decrease in glass transition and crystallization temperature, it provided better condition for the crystallization. It was supported by XRD results that the patterns of the sample including higher boron waste exhibited higher peak intensities compared to the others. Better crystallization conditions by means of boron waste addition has a positive effect on hardness. As an expected result, fracture toughness decreased. In the SEM microstructure, compact and dense structures were observed. At the same time, the effect of boron waste on crystallization was shown in the SEM images. Grains and grain boundaries in the samples including high boron waste were more specific than the samples including low boron waste.

\section{Acknowledgments}

This work was funded by Sakarya University Research Fund under the contract number 2012-01-08-022. The authors would like to express their gratitude to Sakarya University Engineering Faculty, and Prof. H. Akbulut, the head of the Department of Metallurgy and Material Engineering for supporting this work.

\section{References}

[1] K. Al-Zboon, M.S. Al-Harahsheh, F.B. Hani, J. Hazardous Mater. 188, 414 (2011).

[2] M. Ahmaruzzaman, Prog. Energy Combust. Sci. 36, 327 (2010).

[3] I. Acar, M.U. Atalay, Fuel 106, 195 (2013).

[4] S. Nishihama, Y. Sumiyoshi, T. Ookubo, K. Yoshizuka, Desalination 310, 81 (2013).

[5] S. Kurama, A. Kara, H. Kurama, J. Europ. Ceram. Soc. 26, 755 (2006).

[6] S. Ruengsri, J. Kaewkhao, P. Limsuwan, Proc. Eng. 32, 772 (2012).

[7] G.G. Qian, Y. Song, C.G. Zhang, Y.Q. Xia, H.H. Zhang, P.C. Chui, Waste Management 26, 1462 (2006).

[8] M. Erol, S. Kucukbayrak A. Ersoy-Mericboyu, J. Hazard. Mater. 153, 418 (2008).

[9] J.M. Wu, S.P. Hwang, J. Am. Ceram. Soc. 83, 1259 (2000). 